\title{
Globalisation, organisational modes and the growth of international strategic technology alliances
}

Citation for published version (APA):

Narula, R., \& Hagedoorn, J. (1997). Globalisation, organisational modes and the growth of international strategic technology alliances. MERIT, Maastricht Economic Research Institute on Innovation and Technology. MERIT Research Memoranda No. 011 https://doi.org/10.26481/umamer.1997011

Document status and date:

Published: 01/01/1997

DOI:

10.26481/umamer.1997011

Document Version:

Publisher's PDF, also known as Version of record

\section{Please check the document version of this publication:}

- A submitted manuscript is the version of the article upon submission and before peer-review. There can be important differences between the submitted version and the official published version of record. People interested in the research are advised to contact the author for the final version of the publication, or visit the DOI to the publisher's website.

- The final author version and the galley proof are versions of the publication after peer review.

- The final published version features the final layout of the paper including the volume, issue and page numbers.

Link to publication

\footnotetext{
General rights rights.

- You may freely distribute the URL identifying the publication in the public portal. please follow below link for the End User Agreement:

www.umlib.nl/taverne-license

Take down policy

If you believe that this document breaches copyright please contact us at:

repository@maastrichtuniversity.nl

providing details and we will investigate your claim.
}

Copyright and moral rights for the publications made accessible in the public portal are retained by the authors and/or other copyright owners and it is a condition of accessing publications that users recognise and abide by the legal requirements associated with these

- Users may download and print one copy of any publication from the public portal for the purpose of private study or research.

- You may not further distribute the material or use it for any profit-making activity or commercial gain

If the publication is distributed under the terms of Article $25 \mathrm{fa}$ of the Dutch Copyright Act, indicated by the "Taverne" license above, 
Globalisation, organisational modes and the growth of international strategic technology alliances

\section{Rajneesh Narula and John Hagedoorn}

October 1997

Corresponding author: Professor John Hagedoorn

MERIT, Faculty of Economics and Business Administration, University of Maastricht, P.O.

Box 616, 6200 MD Maastricht (Netherlands) - telephone (31)43-3883897- fax: (31)43-

3216518

E-mail: J.Hagedoorn@mw.unimaas.nl 
Abstract The growing use of strategic technology partnering (STP) as a means to undertake technological development is often regarded as a hallmark of globalisation. We attempt to understand and explain this growth. We also attempt to understand the reasons for the choice of different types of organizational modes by firms undertaking STP. In particular, we analyze the growing use of non-equity agreements. Our analysis suggests that the preference for non-equity STP has occurred uniformly across firms of all nationalities, and differences that exist in this propensity are determined by industry-specific differences, rather than country-specific differences. 


\section{Globalisation, organisational modes and the growth of international strategic technology alliances}

\section{Introduction}

The advent of globalisation is by no means a very recent phenomenon. It is only recently, however, that its effects have been recognised as pervasive, with the explosion of international trade and investment by companies of almost every nationality. By now only some aspects of modern commerce are purely domestic. There are few companies that are not engaged in buying inputs or selling outputs in overseas markets and there are even fewer firms who are not affected in some way by economic events in other countries. Relatively unrelated economic phenomena in far-off lands affect even the smallest entrepreneur in the most remote location as goods and services are traded on a global basis.

This effect naturally varies across industries, and is particularly acute in those sectors where consumption patterns are increasingly homogenous across countries, those which are capital - and knowledge-intensive and those that depend on new and fast-evolving technologies. These are sectors where firms have expanded internationally fastest, as they are thus able not just to compete in the various markets simultaneously, they are also able to exploit and acquire assets and technology that may be specific to particular locations. The oft-cited examples of silicon valley in the US as a haven for information technology firms, and the Baden-Wurtenberg region in Germany for chemical firms are just some of the best known cases of this agglomeration effect of innovatory activities.

It is axiomatic that firms in many sectors need to innovate in order to survive, which in this day and age also implies being present in all the major international markets where 
competitors are present. Unfortunately, given the capital-intensity of these activities and the inherent risk of innovation, most firms cannot afford to be omnipresent. Undertaking all or even most aspects of value-adding activities through wholly owned subsidiaries in all locations, is no longer possible, and in many instances not even desirable. Over the past two decades firms have increasingly sought to undertake activities through collaborative efforts. Although collaborative activity is undoubtedly an ancient practice its recent popularity is relatively new. It is undeniable that there is clearly a process of evolution whereby the use of alliances as an explicitly strategic activity represents a 'new' form of commercial activity. What is particularly unique about the current stage of capitalism is the use of alliances to undertake innovative activity, and doing so not just at a centralised location but in international locations often with international competitors. It seems that within strategic technology partnering (STP), there has been a gradual shift away from equity-based partnering to non-equity forms of agreements (Hagedoorn, 1996). The rest of this article focuses on evaluating some of these trends. We do so through the use of the MERIT CATI database, which contains information on almost 8000 instances of STP (see appendix for a description).

This paper examines the changes that have taken place due to globalisation, from three perspectives. First, we try and explain the reasons behind the growth of STP as a phenomenon related to globalisation. Second, we try and understand why firms undertake STP, and particularly, international STP. Third, we evaluate the reasons that determine the choice of different organisational modes of STP - why do firms increasingly prefer non-equity agreements over equity agreements. Although the analysis is of a tentative nature, we try and show that differences are mediated more by industry-specific factors rather than geographic- 
specific factors.

\section{Explaining strategic technology partnering: some definitions}

It is germane to begin this discussion with some fundamental definitions of terms as used throughout this article. Before proceeding further, some distinction needs to be made of the difference between the following three terms which are often mistakenly used as synonyms: collaborative or cooperative agreements, networks and strategic alliances. Cooperative agreements include all inter-firm cooperative activity, while strategic alliances and networks represent two different (though related) subsets of inter-firm cooperation.

By strategic alliances we refer to inter-firm cooperative agreements which are intended to affect the long-term product-market positioning of at least one partner (Hagedoorn 1993). In this paper we are specifically interested in STP where innovative activity is at least part of the agreement. What differentiates a strategic alliance from a customer- supplier network (as well as networks such as the Japanese Keiretsu) is the underlying motive of the cooperation (Figure 1). This differentiation has its roots in an ongoing debate within the management literature of the relative merits of various underlying theories explaining the behaviour of firms to use markets and hierarchies (see Madhok 1996 for a more in-depth analysis of the various aspects of this debate). On the one hand, there is the transaction costs/internalisation perspective, which derives its roots in the work of Williamson (e.g., 1975) and Coase (1937) which explains the behaviour and organisational mode and the mode of entry of firms based on their need to minimise net transaction costs faced by the firm. This body of literature has been expanded by others including Buckley and 
Casson (1976), Hennart (1993) and Rugman (1986). On the other hand, there lie the organisational capability and technology based view of the firm developed in parallel by several schools, including behavioural theory (Cyert and March 1963) and the economics of technological change (Nelson and Winter 1982). More recent work includes that of Kogut and Zander (1993) and Hill, Hwang and Kim (1990), and Cantwell (1991) among others who have highlighted the fact that firms undertake decisions based on the need to enhance their technological and organisational capabilities because they need to enhance the value of the firm. Underlying the difference between these two perspectives is a fundamentally different view of the way firms make decisions, since the transactions cost school assumes that firms are driven by opportunism while the technology/knowledge view assumes that firms are boundedly rational. We do not intend to debate the views here, but accept Madhok's (1996) perspective that the two schools may be regarded as complementary to each other, although a organisational learning and technology based view underlies our understanding of strategic technology partnering.

Our view, following that of Narula and Dunning (1997) and Madhok (1997) is that both transaction cost minimising and value-enhancing reasons underlie most of the behaviour of firms and represent two ends of a continuum. In other words, there are two imperatives to the behaviour of firms (Figure 1). Decisions to vertically quasi-integrate through a collaboration with suppliers may tend to be primarily cost-economising and may be defined as customer-supplier networks. On the other hand, cooperative agreements such as between Sony and Philips to develop DHD technology, or the Sematech partnership are clearly aimed at improving the future value of the various partnering firms and are thus more strategically motivated rather than cost-economising. 
$* * * * * * * * *$ Figure 1 about here $* * * * * * * * * * *$

\section{Globalisation and the growth of strategic technology partnering}

Globalisation as a concept appears much abused. We therefore begin by providing a basic definition. Globalisation as used here is taken to signify the growing convergence of income levels, consumption patterns and technological assets between industrialised and several industrialising countries, and the increasing interdependence between these countries (Dunning and Narula 1997). The relationship between globalisation and strategic alliance activity of firms has received much attention, and is broadly summarised in Figure 2. We shall therefore run through the primary features of this relationship. First, that firms from the converging economies - essentially those from the Triad (Europe, North America and Japan) are increasingly engaged in cross-border economic activity. Indeed, in order to survive, these companies have had to adopt policies that maximise their presence in not just those locations which are their primary markets, but also all those locations where their competitors are operating, in a variant of what was described by Knickerbocker (1973) as a follow-my-leader strategy. This increasing network-like behaviour of MNE activity is prompted in part by the continuing heterogeneity in the supply conditions of countries. That is, despite increasing similarities in consumption patterns and the types of technologies used in each country, there remains a clear specialisation of locations and firms from those locations that has become 
more, rather than less distinct (Narula 1995) ${ }^{1}$. The effect of this has been that firms have an increasing interest in exploiting existing knowledge-based assets and developing new ones in several locations simultaneously to exploit the differing competitive advantages of each location. Second, there has been an increasing interdependence of technologies and industries, such that considerable cross-fertilisation occurs between sectors. For instance, automobile production is no longer simply a matter of a mastery of mechanical technologies, but requires interdisciplinary expertise in, among other things, new materials technology, telecommunications technology, and semiconductor development. The growing costs of acquiring a competitiveness in these several areas simultaneously means that internalising and integrating both horizontally and vertically is no longer possible. Take into account, too, the rising costs of innovation - for instance, a new car can costs several hundreds of millions of dollars to develop - and since the firm must now innovate in several diverse and different sectors simultaneously, it becomes clear that wholly-owned subsidiaries and the internalisation of all $\mathrm{R} \& \mathrm{D}$ activity is no longer a practical solution if a firm wishes to achieve the necessary economies of scale and scope. Ergo, firms wishing to remain competitive in any given market must find ways and means to recover the costs of innovation, and this implies increasing its demand by expanding overseas. However, to do so ensues even higher costs and risks and thus firms must seek partners to share the costs and risks with, rather than simply through foreign direct investment (FDI). Despite the peculiar difficulties with partnering particularly those associated with their high failure rate (see Inkpen and Beamish

\footnotetext{
${ }^{1}$ This has been described as the factors that make up the national systems of innovation. See Lundvall [ed.] (1992) and Nelson [ed.] (1993).
} 
1997) compounded by those peculiar to undertaking innovative activities (for a summary see Narula and Dunning 1997), there has been a growing number of alliances being undertaken with these intentions in mind, although sales and marketing activities dominate alliance activity, particularly in international arena. Nonetheless, in two independent surveys of alliances, both Culpan and Kostelac (1993) and Gugler and Pasquier (1996) found that while sales and marketing accounted for $41 \%$ and $38 \%$ of alliances of their total surveys, R\&D alliances accounted for $10.8 \%$ and $13 \%$ respectively. Gugler and Pasquier (1996), also note, however, that the share of R\&D alliances in the total has tripled since the early 1980 s.

****** FIGURE 2 and 3 HERE ******

Although the CATI database focuses exclusively on alliances that involve innovative activity and thus does not allow us to distinguish the relative significance of STP to other strategic alliance activity, it does confirm the rapid growth since the early 1980s (Figure 3). Alliances grew at an annual average rate of $10.8 \%$ per year between 1980 and 1994, far higher than the growth of R\&D expenditures, taken either on a country or a firm by firm basis. Nonetheless, over the period in question, Triad firms were involved in $94.6 \%$ of alliances established.

\section{Trends in international strategic technology partnering}


What are the trends in strategic technology partnering, and what factors determine the propensity of firms, both by industry and home country, to undertake strategic partnering, both internationally and domestically? Table 1 provides clear evidence that the propensity to undertake STP varies considerably by country, which shows the total number of alliance undertaken by firms of some of the most important home countries of industrial firms. As found by Freeman and Hagedoorn (1994) these countries account for almost $95 \%$ of all strategic technology partnering activity. However, there remain very distinct differences in the propensity of firms to engage in STP that seem to vary by country. For instance, the firms from US, Japan and Germany are engaged in $64.1 \%, 25.6 \%$ and $11.3 \%$ of all alliances included in the sample respectively. Several reasons have been proposed for this, and based on some of the additional variables presented in Table 1 we propose to undertake a casual examination of some of these relationships ${ }^{2}$. First, that the level of technological sophistication of the country plays a key factor in the propensity of its firms to undertake STP, both in terms of undertaking high levels of R\&D activity, as well as being involved in high-tech (and therefore high R\&D intensity) sectors. We include in Table 1 two proxies for this: the share of OECD high tech export market share of these countries (source-OECD) and the level of business expenditure on R\&D in these countries (source-OECD). Second, the structure of the domestic sector plays an important role in determining the ability to undertake STP. On the one hand, countries such as Italy tend to be dominated by small and medium size enterprises, whereas countries such as the UK and US tend to have larger firms dominating

\footnotetext{
${ }^{2}$ We have taken a recent year for each of the variables used here. These variables vary only very gradually from year to year, and as such the choice of year is irrelevant to our results, in addition to which we have used rank correlations which are not affected by absolute numbers but relative levels.
} 
the industrial landscape. This is important, since large firms tend to undertake more R\&D activity, and are thus more likely to undertake STP. We proxy this by the total number of firms from each of these countries that are included in the Fortune 500 list. In addition, large firms also tend to be associated, very often, with large countries, because larger demand fosters firms which produce on a larger scale. All else being equal, countries with a large domestic demand should have a higher propensity to undertake STP. This is measured through an inclusion of the population of each country. Table 2 shows the Spearman rank correlation $^{3}$ of STP against these variables. All the variables we mentioned here are highly significantly related to the number of alliances by each of these countries at the $1 \%$ level.

$* * * * * * \mathrm{TABLE} 1$ and 2 ABOUT HERE*******

Nonetheless, it is important to remember that strategic technology partnering is essentially a firm-level phenomenon. As Table 3 shows, although we can aggregate variables for countries, there is a tendency to generalise a firm-specific activity, even though each firm is idiosyncratic and unique. This is particularly true when it comes to strategy as well as its

\footnotetext{
${ }^{3}$ We use Spearman correlations instead of Pearson correlations because export market share is not normally distributed. However, for those variables that are normally distributed, the Pearson correlations reflect the same relationships at the same significance levels.
} 
technology management. Some firms may prefer to internalise, as much as possible, its innovative activity (such as Volkswagen), while others prefer to undertake joint research activities (such as Nissan). Indeed, when we try to examine the relationship between the propensity undertake STP and firm-level proxies for competitiveness (R\&D expenditures, $R \& D$ intensity) and firm size (sales and employees) the results are much more ambiguous (Table 2). Both R\&D intensity and R\&D expenditure are uncorrelated to STP, while the size variables are, although the relationship is much weaker than on the country level. These results are somewhat influenced by the domination of large firms in table 3, but also suggest that there is considerable variance on a firm-level in R\&D strategy.

****TABLE 3 ABOUT HERE******

What of the international aspect of STP? About 65\% of Triad alliances are international alliances (Table 1), although this varies tremendously between countries. At the one extreme, $41 \%$ of all alliances by US firms have been internationally oriented. At the other extreme, 96\% of Spanish alliances have involved at least one non-Spanish firm. In general, it would seem that European firms tend to have a much higher share of international alliances than US or Japanese firms.

There are several underlying reasons for the different levels of international participation in alliances by country. First, there are country-size effects - small countries tend to have a higher involvement in international investment and overseas production compared to large countries. This is because local demand is often (as in the case of the US) 
sufficient to achieve economies of scale in large countries, while small country firms must seek overseas markets to achieve similar economies (Narula 1995). In general therefore, small country firms will show a greater propensity to engage in international strategic alliances. In addition, small countries tend to be specialised in fewer sectors and niches (Hagedoorn and Narula 1996), and if they need to access technologies outside these niche sectors, they are obliged to seek access to these comparative advantages in other locations. The reverse is true for the US, which, as a large country, possesses comparative advantages in several industries, and is home to agglomerative clusters in most of these. This acts as a disincentive for US firms to venture overseas to engage in innovative activity, as it does toward overseas production - on a per capita basis, the US has engages in a very low level of FDI activity. A rank correlation between country size (proxied by population) and international STP gives a coefficient of -0.688 , which is significant at the $1 \%$ level.

Second, there are general broad differences in strategy between firms of different nationalities and regions. Veugelers (1995) observes that, among other things, (a) EU have a higher propensity to engage in alliances in sectors in which they lack a comparative advantages relative to US and Japanese firms, (b) strong EU and Japanese firms seek weak partners, seeking markets and technology, while controlling potential competition. Indeed, Narula (1997) notes that EU firms have a higher preference for equity agreements when undertaking intra-EU alliances, but not when partnering with a US firm. This is the reverse of the situation of US firms which have a low propensity to use equity for intra-US alliances and a higher level for international alliances.

Table 3 also provides details on a firm-level regarding the propensity to undertake international strategic technology partnering. It would seem there is a strong positive 
correlation between the extent to which firms are engage in international production proxied by the percentage of foreign employees in the total employees, and the percentage of international STP (Table 4). Interestingly, there seems to be a negative and significant correlation between international STP and size, proxied by sales, which might indicate that firms compensate for their small size by engaging in international STP.

********TABLE 4 ABOUT HERE********

Are there any significant differences by region in the extent of STP and international STP? Taking one-way ANOVA test to examine difference between means after dividing the sample into European, Japanese and US firms, there appears to be no significant difference between the 3 groups ${ }^{4}$. However, when we classify the firms in Table 3 by broad industrial sector (IT/electronics, automobiles and chemicals) we find that significance differences exist between the groups' means for both STP and international STP at the 5\% level of significance. In both cases, the electronics/IT sector demonstrates a much higher mean participation in STP and international STP than the other two sectors.

\footnotetext{
${ }^{4}$ Due to the limited sample size of 1 in the food sector, Unilever was excluded from this analysis.
} 


\section{Organizational modes of strategic technology partnering}

Collaborative agreements of all sorts have been undertaken for strategic, economic and diplomatic reasons since the beginning of history. However, what differentiates their current popularity is that until recently they represented a second-best option, utilised only where full internalisation were not possible. It was conventional wisdom that firms preferred, wherever possible, to establish wholly owned subsidiaries, and where this was not possible for whatever reason, to maintain a controlling (which generally implied majority-) stake in its affiliate. In general, firms preferred to maximise their equity stake in all their activities, particularly so when entering or expanding in foreign markets. Over the past two decades or so, alliances and networks have come to represent an increasingly important option, in what has been described as an age of alliance capitalism (Dunning 1995). Indeed, there are four primary characteristics that differentiate collaborative activity in the era of alliance capitalism from those in earlier periods (Narula and Dunning 1997). First, agreements are not primarily made to overcome market failure. Second, alliances are increasingly made not just to achieve vertical integration, but also horizontal integration. Third, alliance activity is no longer a phenomenon peculiar to certain countries such as Japan (see Gerlach 1992), but typical of most advanced industrialised economies. Fourth, while agreements were primarily made to enhance or achieve market entry or presence (i.e., asset-exploitation), an increasing number of alliances are now made to protect or enhance the technological assets of firms (i.e., assetcreation or acquisition). 
Figure 4 describes the range of inter-firm organisational modes generally utilised in collaborative agreement activity: There are a wide range of types of agreements, reflecting various degrees of inter-organisational interdependency and levels of internalisation. These range from wholly-owned subsidiaries, which represent completely interdependency between the firms and full internalisation. At the other extreme, lie spot-market transactions, which totally independent firms engage in arms-length transactions in which either firm remains completely independent of the other. As Figure 4 illustrates, we include within the rubric of collaborative agreements two broad groupings of agreements which can be regarded as representing different extents of internalisation, or what may succinctly be described as quasiinternalisation. Although it is difficult to be specific and concrete regarding the ordinal ranking, it is safe to say that equity-based agreements represent a higher level of internalisation and inter-organisational interdependence than non-equity agreements.

There is clear evidence that over the past two decades there has been a growing use of non-equity agreements. This trend is particularly noticeable within strategic technology partnering - Table 5 gives details of types of agreements using the general groupings presented in Figure 4. Non-equity STP have increased from 53.1\% of all agreements undertaken between 1980 and 1984, to about 73.3\% of agreements between 1990 and 1994 .

*******TABLE 5 ABOUT HERE********

On the surface, this change in preference reflects some of the aspects of globalisation. 
Equity agreements tend to be much more complex forms to administer and control, and take longer to establish and dissolve (Harrigan 1988). In addition, globalisation in certain fastevolving sectors such as information technology has led to shorter product life cycles. Along with increasing competition in the race to innovate, this has tended to encourage firms to engage in contractual, non-equity STP which provide greater strategic flexibility, since firms need to have quick responses to changes in technological leadership. A second effect of globalisation has been the increasing homogeneity of socio-economic conditions, which have brought some level of harmonisation in the legal and regulatory frameworks across countries. In some instances this has occurred on a regional basis, such as within the EU, while in others it has occurred on a near-global basis through institutions such as the World Trade Organisation and the World Intellectual Property Organisation. As Table 1 and 3 have shown, a large percentage of alliances tend to be international in scope, and given the nature of innovative activity, there is considerable risk that there may be asymmetrical learning within an agreement, with the firm that has learnt the most terminating the agreement prematurely ${ }^{5}$. Such situations would result in the loss of proprietary and firm-specific technological assets. Particularly in the case of cross-country partnerships, it is much harder to seek legal recourse for such loss. Firms in international alliances have thus tended to prefer equity agreements. However, with the development of cross-national institutions and the gradual standardisation of regulatory frameworks, firms are increasingly able to undertake non-equity agreements on an international basis, since contracts are more readily enforceable.

\footnotetext{
${ }^{5}$ Described by Das and Teng (1996) as 'performance risk'.
} 
In addition to such exogenous changes, however, there is the organisational learning aspect. As firms acquire experience undertaking overseas activity, their perception of the inherent risk in undertaking overseas alliances falls. In addition, as firms become more familiar with a given partner, the risk that specific partner will be dishonest declines with every subsequent agreement.

********TABLE $6 \mathrm{ABOUT} \operatorname{HERE} * * * * * * * *$

Another aspect of the move to towards non-equity agreements is that while this shift has occurred in general amongst firms of all nationalities (including developing country firms - see Narula and Sadowski 1998), there are clear differences between regions. Table 6 shows how the decline in the popularity of equity agreements has happened in all the different geographical regions of the Triad. Interestingly, although the percentage of non-equity STP by US firms was highest during the most recent period $(77.8 \%)$ relative to European and Japanese firms, between 1980 and 1984, Japanese firms showed a much higher propensity for non-equity STP than did the US. This is a particularly interesting observation, since Japanese firms have been noted to have a preference for wholly-owned subsidiaries when undertaking overseas production. The dominance of non-equity agreements by US firms is not entirely unrelated to the fact that the US has the smallest percentage of international alliances. Taking a pearson correlation of international alliance formation and equity alliance we get a coefficient of 0.73 , which is significant at the $1 \%$ level. Nonetheless, although our data in Table 3 is limited in sample size, by breaking down the firms by region, there appear to be no 
significant differences in the mean propensity to undertake equity alliances by geographical region.

On the other hand, there is some evidence to indicate that the ability of participating firms to discover knowledge and then implement it varies according to the organisational form of the of the alliance (Osborn and Baughn 1990, Hagedoorn and Narula 1996). As such, firms select particular alliance form depending on the objective and industry of the alliances. For instance, non-equity forms of agreements are more efficient for undertaking more research intensive activity, since they promote negotiation and intensive cooperation than equity forms. However, where firms seek to learn and transfer tacit knowledge back to the parent firm, such as market-specific knowledge when entering a new market, or are engaged in production as well as research, equity forms of agreement may be more appropriate (Osborn and Hagedoorn 1997). In general, though, it would appear that the choice of particular mode of cooperation varies with the technological characteristics of sectors of industry. Equity agreements are preferred in relatively mature sectors, while non-equity agreements are utilised in high-tech sectors (Hagedoorn and Narula 1996). Some effort has been made to relate the choice of type of equity versus non-equity agreements from several aspects. Work by Prevezer and Toker (1996) indicates that in the biotechnology sector, the type of alliance depended upon the relative sizes of the firms as well as the extent of appropriability of the innovation. In respect to size, they found that contractual agreements were more likely involving small companies, while equity agreements were more common among alliances between large firms. They argue that in industries where appropriability of innovation (whether through patenting or other means) was more effective, and there were no bargaining problems, technologies were close to existing competencies, contractual 
agreements were more feasible.

Although the data presented here is limited, when we examine the firm-level data in Table 3 and evaluate the propensity of firms to undertake equity alliances using a broad breakdown of the firms by industrial sector with a one-way ANOVA model, we find that significant differences exist between industrial groups of firms, albeit at the $10 \%$ level of significance. Narula (1997) observes that on a higher sectoral diasaggregation, that differences do exist between the propensities of companies to undertake equity-type STP depending on the bilateral partner nationalities, but these differences are not significant between intra-EU alliances, EU-Japanese alliances and EU-US alliances, but are significantly different for intra-US alliances.

This would suggest that in fact, globalisation has had some broad effects on the propensity of firms to undertake non-equity alliances, and has led to a homogenisation of the propensity of firms to undertake alliances. where differences do exist they represent interindustry differences and particularly those relating to industry-specific characteristics.

\section{Conclusions}

Our analysis lends support to, and confirms, some of the trends and patterns observed by various other the technology partnering literature. First, that strategic technology partnering as a phenomenon is best explained using an organisational learning framework. Recent theoretical studies have suggested that firms' decisions regarding what extent to internalise value adding activity is determined not just by a cost minimisation strategy driven by short term profit optimisation, but also by an interest to enhance the value of the firm in a more 
long term horizon. It does so by improving the nature and types of technological/knowledgebased assets its possesses. Given the firm's bounded rationality, however, this decision is more of a strategic one. This is what determines the primary difference between networks and alliances.

There has clearly been a explosion in the use of alliances to undertake innovative activity, and this trend is closely related to the process of globalisation. Globalisation has affected the need of firms to collaborate, in that firms now seek opportunities to cooperate, rather than identify situations where they can achieve majority control. In addition, the increasing similarity of technologies across countries and cross-fertilisation of technology between sectors, coupled with the increasing costs and risks associated with innovation has led to firms frequently utilising alliances. STP, as with most forms of innovative activity, is primarily concentrated in the Triad countries. However, the propensity of firms of a given nationality to engage in STP varies according to the characteristics of the country. This is because small and technologically less advanced countries tend to be focused in fewer sectors than large countries, due, inter alia, to the differences in economic structure and demand. We also see that strategic alliances are dominated by large firms, and there is indeed a positive relationship between firm size and STP levels by firm. We also observe a high percentage of STP utilised on a cross-border basis. That is, a considerable share of STP seems to be undertaken to with partners of other nationalities. There seems to be some suggestion that while some firms undertake STP as a means to complement their existing R\&D activity, other seek to use STP as a substitute.

There seems to be no clear relationship to the extent to which firms engage in international production and engage in technology partnering. This difference is not 
mediated, as might have been expected, by nationality of ownership or by R\&D expenditures, but preliminary indications suggest that it differences exist on a sectoral basis, suggesting that it is a industry-specific phenomenon.

There is also a clear shift of alliance activity towards non-equity forms of agreements, and this has occurred more or less uniformly across countries, and we attribute this change partly to the improved enforceability of contracts and intellectual property protection, and partly to the increasing knowledge and familiarity firms now have in conducting international business activity. On a firm level basis, the propensity to use equity agreements is associated with industry-specific differences, rather than country-specific differences.

\section{References}

Buckley, P. and Casson, M. (1976) The Future of the Multinational Enterprise, Holmes \& Meier, New York

Coase, R. (1937) The Nature of the Firm, Economica vol, 4, no 4, November

Culpan, R. and Kostelac, E. (1993) Cross national corporate partnerships: trends in alliance formation, R. Culpan (ed) Multinational Strategic Alliances, International Business Press, New York, pp103-122

Cyert, R. and March, J. (1963) A Behavioural theory of the Firm, Prentice Hall, Englewood Cliffs.

Das, T., and Teng, B-S. (1996) Risk types and inter-firm alliance structures, Journal of 
Management Studies, Vol. 33, pp 827-843

Dunning, J.H. (1995) Reappraising the eclectic paradigm in the age of alliance capitalism, Journal of International Business Studies Vol. 26, pp 461-91

Dunning, J.H. and Narula, R. (1997) Developing countries versus multinationals in a globalising world: the dangers of falling behind, in P. Buckley and P. Ghauri (eds), Multinational enterprises and emerging markets, London: Dryden Press, forthcoming.

Freeman, C. and J. Hagedoorn (1994) Catching up or falling behind: patterns in international inter-firm technology partnering, World Development Vol.22, pp.771-780.

Garcia-Canal, E. (1996) Contractual form in domestic and international strategic alliances, Organization Studies, Vol 17, pp 773-794

Gerlach, M (1992) Alliance Capitalism, Oxford: Oxford University Press

Glaister, K. and P. Buckley (1996) strategic motives for international alliance formation, Journal of Management Studies Vol 33, pp 301-332

Gugler, P. and Pasquier, M. (1996) Strategic alliances of Swiss firms: theoretical considerations and empirical findings, Institut fuir markeing und unternehmungsfuhrung working paper no 27

Hagedoorn, J. (1993) Understanding the rationale of strategic technology partnering: Interorganizational modes of cooperation and sectoral differences, Strategic Management Journal, Vol 14, pp371-385

Hagedoorn, J. (1996) Trends and patterns in styrategic technology partnering since the early seventies, Review of Industrial Organization, Vol. 11, pp. 601-616.

Hagedoorn, J. and Narula R. (1996) Choosing modes of governance for strategic technology partnering: international and sectoral differences, Journal of International Business Studies, Vol. 27, pp 265-284 
Harrigan, K. (1988) Strategic alliances and partner asymmetries, in F. Contractor and P. Lorange (eds), Cooperative strategies in International Business, Lexington, Lexington Books

Hennart, J.-F. (1993) Explaining the swollen middle; why most transactions are a mix of market and hierarchy, Organization Science, Vol 4, pp529-547

Hill, C. Hwang, P. and Kim, W. (1990) An eclectic theory of the choice of international entry mode, , Strategic Management Journal , Vol 11, pp117-128

Inkpen, A. and Beamish, P. (1997) Knowledge, bargaining power, and the instability of international joint ventures, Academy of Management Review, Vol. 22, pp 177-202

Knickerbocker, F.T. (1973) Oligopolistic Reaction and the Multinational Enterprise. Cambridge, MA.: Harvard University Press.

Kogut, B. and Zander, U. (1993) Knowledge of the firm and the evolutionary theory of the multinational enterprise, Journal of International Business Studies, Vol 24, pp625-646

Lundvall, B.(1992) National Systems of Innovation: Towards a Theory of Innovation and Interactive Learning, London, Pinter Publishers

Madhok, A. (1997) Cost, value and foreign market entry mode: the transaction and the firm,

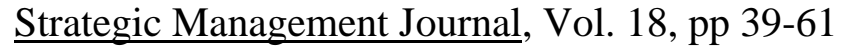

Madhok, A. (1997) Strategic alliances as simultaneous failure of markets and hierarchies: a knowledge-based perspective and implications for the firm, University of Utah, mimeo

Narula, R. (1995) Multinational Investment and Economic Structure, Routledge, London

Narula, R. (1996) Forms of International Cooperation Between Corporations, in C. Jepma and A. Rhoen (eds) International Trade: A Business Perspective, Longman, Harlow, pp 98-122

Narula, R. (1997) International Strategic Technology Partnering by EU Firms: Globalisation 
or Integration?, University of Maastricht, mimeo

Narula, R. and Dunning, J. 1997) Explaining International R\&D Alliances and the Role of Governments, MERIT Working Paper Series 97-011

Narula, R. and Sadowski, B. (1998) Technological Catch-up and Strategic Technology Partnering in Developing Countries, International Journal of Technology Management, Forthcoming 1998

Nelson, R. and Winter, S. (1982) An Evolutionary Theory of Economic Change, Belknap Press, Cambridge

Nelson, R. R. (ed.) (1993), National innovation systems, New York, Oxford University Press.

Osborn, R. and Baughn, C. (1990) Forms of Inter-Organisational Governance ffor Multinational Alliances, Academy of Management Journal, Vol 33, pp 503-519

Osborn, R. and Hagedoorn, J. (1997) The institutionalisation and evolutionary dynamics of inter-organizational alliances and networks, Academy of Management Journal, Vol 40, pp 261-278

Prevezer, M. and Toker, S. (1996) The degree of integration in strategic alliances in biotechnology, Technology Analysis and Strategic Management, Vol 8, 117-133

United Nations (1996) World Investment Report 1996, Geneva: United Nations

Veugelers, R. (1996) alliances and the pattern of comparative advantages: a sectoral analysis, International Business Review, vol. 4, pp 213-31

Williamson, O.E. (1975) Markets and Hierarchies: Analysis and Anti-Trust Implications, Free Press, New York 


\section{Appendix The Cooperative Agreements and Technology Indicators (CATI) information system}

The CATI data bank is a relational database which contains information on nearly 10,000 cooperative agreements involving some 3500 different parent companies has been collected. Systematic collection of interfirm alliances started in 1988. If available, many sources from earlier years were consulted enabling us to take a retrospective view. In order to collect interfirm alliances we consulted various sources, of which the most important are specialized journals which report on business events.

This method of information gathering which we might call 'literature-based alliance counting' has its drawbacks and limitations:

- In general we have only come to know those arrangements that are made public by the companies themselves.

- Newspaper and journals reports are likely to be incomplete, especially when they go back in history and/or regard firms from countries outside the scope of the journal.

- A low profile of small firms without well-established names is likely to have their collaborative links excluded.

Despite such shortcomings, which are largely unsolvable even in a situation of extensive and large-scale data-collection, we think we have been able to produce a clear picture of the joint efforts of many companies.

The data bank contains information on each agreement and some information on participating companies. The first entity is the inter-firm cooperative agreement. We define cooperative agreements as common interests between independent (industrial) partners which are not 
connected through (majority) ownership. In the CATI database only those inter-firm agreements are being collected, that contain some arrangements for transferring technology or joint research. We also collect information on joint ventures in which new technology is received from at least one of the partners, or joint ventures having some R\&D program. Mere production or marketing joint ventures are excluded.

We regard as a relevant input of information for each alliance: the number of companies involved; names of companies (or important subsidiaries); year of establishment, duration and year of dissolution; field(s) of technology; modes of cooperation. Depending on the form of cooperation we collect information on equity sharing; the direction of capital or technology flows; the degree of participation in case of minority holdings; some information about motives underlying the alliance; the character of cooperation, such as basic research, applied research, or product development possibly associated with production and/or marketing arrangements.

The second major entity is the individual subsidiary or parent company involved in one (registered) alliance at least. We ascertain its nationality and we determine the main branch in which it is operating and classify its number of employees. In addition to this time-series for employment, turnover, net income, R\&D expenditures and numbers of assigned US patents have been stored. 